\title{
Role of Karmayoga in Personality Development
}

\author{
Dr. Rakhi Sinha \\ Assistant Professor, Department of Political Science, M.M.Mahila College, Ara, Bihar
}

\begin{abstract}
Karmayoga was a path taught by Krishna to his disciple, Arjuna, in the historic spiritual scripture, the Bhagavad Gita. The essence of his Karma Yoga teachings were that one must participate in the world, performing their proper activities without attachments to the outcome while all the while devoting themselves to the path of union with the Divine. Therefore, the term "self-less service" doesn't necessarily imply free work for other. It is doing the work intended for you without any longing for the fruits of this work for the "self." This is extremely difficult not only because it is our conditioning to be attached to the benefits for me but determining what are proper activities and what are not proper activities takes being deeply tune with one's intuition or self. It would be appropriate to use the word 'Yoga" to mean "device" or "intelligent method" and hence the term "karma yoga" would be "a technique for intelligently performing actions." In this paper, I am highlighting certain aspects of Karmayoga for personality development of an individual. How the forms and tecniques of Karmayoga helps in the overall development in order to face the multifarous challenges of life and to make a balance between I and We. To follow Karma Yoga in our contemporary society we need to cultivate a meditation practice to support us in training our minds and our senses to eventually be able to live in this world, doing our worldly duties up to our best abilities with absolutely no longing for the benefits to ourselves. Bringing cleanliness, purity, order and simplicity to our lives, ridding ourselves of restlessness, greed and desire to be able to live in the world. We must act to find inner peace and satisfaction. Developing a daily meditation practice is developing awareness that will bring more awareness to your actions in daily life. I believe this is a very inspiring way to live. It is necessary to enjoy every moment, doing our best to follow the direction of our heart and intuition, to preserve and try to be light and energetic while living in our daily life and doing whatever is necessary to act and follow.
\end{abstract}

Keywords: Karmayoga, Personality development, self-less service, peace, purity, spirituality etc.

\section{INTRODUCTION}

"Karma Yoga is the Selfless Devotion of all the inner and outer activities as a sacrifice to the Lord of All Works, offered to the Eternal as Master of all the Soul's energies and austerities." - Bhagavad Gita.

"Work done in the right attitude becomes consecrated; becomes a sacred act. A life consecrated in doing selfless acts will become a divine life." - Swami Sivananda.

Karmayoga was a path taught by Krishna to his disciple, Arjuna, in the historic spiritual scripture, the Bhagavad Gita. The essence of his Karma Yoga teachings were that one must participate in the world, performing their proper activities without attachments to the outcome while all the while devoting themselves to the path of union with the Divine. Therefore, the term "self-less service" doesn't necessarily imply free work for other. It is doing the work intended for you without any longing for the fruits of this work for the "self." This is extremely difficult not only because it is our conditioning to be attached to the benefits for me but determining what are proper activities and what are not proper activities takes being deeply tune with one's intuition or self. It would be appropriate to use the word 'Yoga" to mean "device" or "intelligent method" and hence the term "karma yoga" would be "a technique for intelligently performing actions."

Our content analysis of Mahatma Gandhi's commentary on the Gita (Gandhi, 194612001) showed that the effects of karma yoga were described as four outcomes viz. freedom from the karmic law of birth and death; attainment of oneness with god; happiness; and peace. Of these four outcomes, the first two describe spirituality while happiness and peace are psychological entity, which can be empirically in nature. According to the Gita, when one does what one has to do, with perfect mental control and after giving up the desire for the result and with a frame of mind that is equal towards pain and happiness, there remains no fear or possibility of experiencing the unhappiness of actions. Hence, the Gita recommends that we keep our organs under control and allow them to perform the various activities, not for a selfish purpose, but apathetically, without desire, and for the welfare of others. Indian philosophy suggests that the path to be selected for liberation must be suited to the temperament and disposition of the seeker. Karma yoga provides one such path for freedom from the cycle of birth and death, which is suited for people with an active temperament who have chosen to remain in the world and aspire for liberation. In order to understand the dimensions of karma yoga, each of the verses of the Gita (Gandhi, 1946/2001) was read by us and the verses were categorized into activities prescribed to reach the ideal state (69 verses); description of the ideal state of a person (145 verses); and outcomes on achieving 


\section{International Advanced Research Journal in Science, Engineering and Technology}

Vol. 8, Issue 6, June 2021

\section{DOI: $10.17148 /$ IARJSET.2021.8635}

the ideal state (76 verses). Karma yoga is the path to reach the ideal liberated state through work and hence we looked into the types of activities prescribed to reach the ideal state. Five types of activities were described in the Gita: performing actions without attachment (16 verses); meditation or focusing on the soul (10 verses); being neutral to opposites, or keeping senses under control (10 verses); and doing one's duty in society (8 verses).

\section{PRACTICE OF KARMA-YOGA TO ENHANCE PERSONALITY DEVELOPMENT}

Personality development plays a vital role on the overall development of an individual. Mere educational temperament can never help an individual to reach to its ultimate goal. Spirituality as well as mental enrichment is too important. Here karmayoga really helps a lot at time when practically we are presenting over selves at various platforms. The more we are confident and energetic both from inside and outside, the more success we may achieve. Hence it is very necessary to follow the following guidelines:

(a)Right Attitude:

We should be realistic and calm in our attitude while performing our work or Karma. Over-confidence has to be avoided in order to be self-less in our attitude.

(b) Correct Aim:

Our aim has to be very clear as well as correct. According to the goal or aim, we need to plan out in a right manner.

(c)Performance of Duty:

Often our specific duty in life is referred to as "Dharma", which means righteousness.

Performance of duty frees the soul, and non -performance of duty keeps the soul in bondage.

(d) Work for one's your best:

Whatever you do, do your best. You will incur demerit if you do not give your best.

If you know of a better way to serve then you must make use of it. You cannot hold back from fear of the effort required or from fear of criticism.

(e) Give up results:

God is the Doer. We are not the Doer; we are only the Instrument. We do not know God's intentions or God's plans. God is the actor. The way to realize this Truth is to constantly work for work's sake and to let go of the outcome, good or bad. It is the desire for action that binds the individual.

(f) Serving God or the Self in All:

Do unto others what you would like to have done to yourself. We have to learn to adapt and adjust. We are all parts of the same body. Practice humility in action. Beware of power, fame, name, praise, and censure.

(g) Follow the Discipline of the Job;

Every work experience has something to teach you. Try to do your best and the lessons of your work will be rich. Each job involves different requirements in terms of time, degree of concentration, skills or experience, emotional input, physical energy, and will.

\section{CERTAIN TECHNIQUES TO FOLLOW}

Certain techniques are essential to follow for personality development by the means of Karmayoga. Meditation is the means by which we control our mind and guide it in a more virtuous direction (Dalai Lama, 2001). Modern brain imaging techniques have even begun to identify the brain regions involved in these processes (Barinaga, 2003). There are many different meditation techniques in Yoga, and no one technique is necessarily better than another. What is most important is to pick one type of meditation and stick with it. Meditation takes practice. Most of us find it very difficult to relax and clear our mind. Even when we do, it is difficult to stay relaxed and keep our mind clear. It helps to have a well-described procedure, and it can be very helpful to meditate in a group. As with all paths toward selfdevelopment, it takes time to progress in your ability to meditate.

Mindfulness is a form of meditation that occurs throughout every moment of the day. Indeed, it is very important to live fully in every moment, and to look deeply into each experience. By being mindful, we can enter into awareness of our body and our emotions. Thich Nhat Hanh relates a story in which the Buddha was asked when he and his monks practiced. The Buddha replied that they practiced when they sat, when they walked, and when they ate. When the person questioning the Buddha replied that everyone sits, walks, and eats, the Buddha replied that he and his monks knew they were sitting, knew they were walking, and knew they were eating. Mindfulness can also be applied to acts as simple as breathing. According to Thich Nhat Hanh, conscious breathing is the most basic Buddhist technique for touching peace.

\section{PERFORMING YOGA FOR PERSONALITY DEVELOPMENT}

There are many schools of Yoga such as Hatha-Yoga, Laya-Yoga, Bhakti-Yoga, Raja-Yoga, Kriya-Yoga, Jnana- 


\section{International Advanced Research Journal in Science, Engineering and Technology}

Vol. 8, Issue 6, June 2021

\section{DOI: $10.17148 /$ IARJSET.2021.8635}

Yoga, Karma-Yoga, and Mantra-Yoga. The purpose of each of these schools of Yoga, in their own way, is to guide the individual toward the fulfillment of their life. This fulfillment is not necessarily enlightenment, or what we in the West may think of as heaven, but may instead be preparation for steadily improving lives over subsequent reincarnations. In accordance with the concept of karma, if we do our best to live this life as a good and faithful person, then in our future lives we will benefit from the seeds of good karma we have planted in this life.

\section{Hatha-Yoga}

Hatha-Yoga is the Yoga of power, referring primarily to the Kundalini energy and prana (vital energy) within the body. The practices of Hatha-Yoga are intended to strengthen and prepare the body for controlling the life forces within. An important aspect is the practice of asanas, the postures that are often misidentified as being Hatha-Yoga itself. Laya-Yoga

Laya-Yoga focuses on meditative absorption of the psyche or mind to the point of ecstatic realization, or samadhi. As an advancement from Hatha-Yoga, Laya-Yoga leaves behind the physical focus of Hatha-Yoga for a highly developed state of meditation in which one's sense of self dissolves into transcendental self-realization.

\section{Bhakti-Yoga}

Bhakti-Yoga is the Yoga of devotion or love, in which the force of human emotion is channelled toward the Divine. This devotion develops along nine stages, the first being to listen to the names of God. The second is to chant praises in honor of the Lord, which is why chanting is so common in the practice of Yoga and Buddhism. The remaining stages involve a variety of practices or rituals. As simple as the first two stages may seem, together they have given rise to a special form of musical prayer: Kirtan, the practice of singing the many names of God.

\section{Raja-Yoga or Kriya-Yoga}

Raja-Yoga, or Royal Yoga, combines the principles, though not necessarily the practices, of other forms of Yoga and thus supersedes them all. Raja-Yoga is that which was originally taught by Patanjali in the Yoga Sutras. It is also known by the name Kriya-Yoga, and it is this term that Yogananda used when bringing Yoga to the United States in 1920. According to Yogananda, this form of Yoga is more than just a practice developed by a great man. Patanjali is believed to be one of the ancient avatars of India, making this form of Yoga a direct divine inspiration.

\section{Jnana-Yoga}

Jnana-Yoga is the Yoga of wisdom or knowledge. It is a rigorous discipline in which one uses the intellect to discern reality from maya. Maya is often misunderstood, and described as the cosmic delusion that our Self is this body in this life. There is no good without evil, no happiness without misery, no beauty without ugliness. Consequently, there will never be a perfect world, a world in which there is no suffering or death. Even the basic existence of the world must be considered in the context of no-existence. This strange and challenging philosophy is described by Vivekananda in the following passage:

\section{Karma-Yoga}

Because we are inseparably compelled by the three aspects of existence, existence involves action. Karma-Yoga teaches us to act without attachment to the consequences of our actions and without any expectations. But it is not enough to control our actions, we must understand why we are controlling our mind. As Krishna tells Arjuna in the third chapter of the Bhagavad Gita: He who controls his actions, but lets his mind dwell on sense-objects, is deluding himself and spoiling his search for the deepest truth. The superior man is he whose mind can control his senses; with no attachment to results, he engages in the yoga of action.

\section{Mantra-Yoga}

Mantra-Yoga is the Yoga of sound or vibration. The universe is believed to be in constant vibration. Om, the most sacred mantra, is believed to be the word representing the fundamental vibration of the universe. As such, meditating while chanting Om is believed to have almost magical transformative powers over the body and mind.

\section{CONCLUSION}

To follow Karma Yoga in our contemporary society we need to cultivate a meditation practice to support us in training our minds and our senses to eventually be able to live in this world, doing our worldly duties up to our best abilities with absolutely no longing for the benefits to ourselves. For personality development, it is needed to bring cleanliness, purity, order and simplicity to our lives, ridding ourselves of restlessness, greed and desire to be able to live in the world. We must act to find inner peace and satisfaction. I believe this is a very inspiring way to live. It is necessary to enjoy every moment, doing our best to follow the direction of our heart and intuition, to preserve and try to be light and energetic while living in our daily life and doing whatever is necessary to act and follow.

\section{REFERENCES}

[1]. Aiyangar, K. V. Rangaswami. 1945. Krtyakalpataru of Bhatta Laksmidhara. Vol. 14. Vadodara: Oriental Institute.

[2]. Besant, Annie. 1907. "An Introduction to Yoga." Found at

[3]. Bhattacharya, Ram Shankar. 1985. An Introduction to the Yogasutra. Delhi: BharatiyaVidya Prakashana. 


\section{International Advanced Research Journal in Science, Engineering and Technology}

Vol. 8, Issue 6, June 2021

\section{DOI: $10.17148 /$ IARJSET.2021.8635}

[4]. Bryant, Edwin. 2009. The Yoga Sutras of Patanjali. New York: North Point Press.

[5]. Dasgupta, Surendranath. 1975. A History of Indian Philosophy. Vol. 1. Cambridge: Cambridge University Press, 1922; Delhi: Motilal Banarsidass (1975 citededition)

[6]. Dvivedi, M. N. 1890. The Yoga-Sutras of Patanjali. Mumbai: Bombay TheosophicalPublication Fund.

[7]. Jacobsen, Autumn. 2008. "Contemporary Yoga Movements." In Yoga: India’s Philosophy of Meditation. Edited by Gerald James Larson and Ram Shankar Bhattacharya, 147-59. Delhi: Motilal Banarsidass.

[8]. Thapar, Romila. 2004. Early India: From the Origins to AD 1300. Berkeley: University of California Press.

[9]. Yamashita, Koichi. 1994. Patanjala Yoga Philosophy with Reference to Buddhism. Kolkata: Firma KLM Private Limited. 